\title{
The Relation of IGF-1 Genotype with Weight in Etawah Grade Goats at Polewali Mandar Regency
}

\author{
Surya $^{1, *}$ Andi Yulyani Fadwiwati ${ }^{1}$ Muhammad Ihsan Andi Dagong ${ }^{2}$ \\ ${ }^{I}$ Agricultural Technology Research Center Gorontalo, Ministry of Agriculture, Gorontalo \\ ${ }^{2}$ Department of Animal Production, Faculty of Animal Science, University of Hasanuddin \\ *Corresponding author.Email: aku.uyha@yahoo.com
}

\begin{abstract}
A study was conducted to the relation of IGF-1 genotype with weight in Etawah Grade goats at Polewali Mandar Regency. The object of this research used 22 Etawah Grade goats that had been weighed and their blood was taken for DNA and PCR-RFLP extraction to determine the diversity of the IGF-1 genotype. The data then calculated the allele frequency and genotype frequency, a simple linear regression analyis, the correlation coefficient, and the coefficient of determination. The research results obtained were that $\mathrm{AA}, \mathrm{AB}$, and $\mathrm{BB}$ genotypes of IGF-1 gene with the most allele frequency and genotype frequency is allele A and AB genotype, simple linear regression equation $\mathrm{Y}=15,46+4,53 \mathrm{X}$ with a correlation coefficient of 0,67 and a coefficient of determination is 0,42 . It was concluded that there was a strong the relationship of IGF-1 genotype diversity with weight in Etawah Grade goats.
\end{abstract}

Keywords: IGF-1 genotype, weight, Etawah Grade goat

\section{INTRODUCTION}

Goats is one of small ruminants have been developed in Indonesia Goats are one of the small ruminants that have been developed in Indonesia. Goats have the ability to adapt and survive the worst environmental conditions [1]. Goats can be classified into the kingdom: Animalia; phylum: Chordata, class: Mammalia; ordo: Artiodactyla; family: Bovidae; subfamily: Caprinae; genus: Capra; species: Capra aegagrus; and subspecies: Capra aegagrus hircus [2].

Indonesia's goat varieties, Etawah Grade goat, can produce meat, milk and skin. Etawah Grade goat is the result of a cross between Kacang goat and Etawah goat that can adapt to the conditions and habitats in Indonesia [3]. Goats have characteristics that are easy to breed, so that they have an important role as a genetic resource.

DNA or commonly referred to as deoxyribonucleic acid is located on the chromosome, seen in the form of double strands that twist each other long with the base groups, namely purines (Adenine and Guanine) and pyrimidines (Cytosine and Thymine), and have a function as a determinant of the type of protein to be synthesized [4]. Genes are widely expressed, such as the growth hormone coding gene together with the IGF-1 gene expression, one which of present in the blood circulation [5].

The potential in Etawah Grade goats can be measured and observed through their weight characteristics. Weight is a trait that are controlled by two or more genes. One important gene that affect weight of goats is the growth hormone coding gene [6], as in the calpastatin gene [7], the IGF-1 gene [8], the leptin gene [9], the pituitary transcription factor-1 gene [10], etc. The IGF-1 gene are the candidates' gene it can be used that selection strategies for using DNA markers.

This study was conducted to the relationship of IGF-1 (Insulin-like Growth Factor-1) genotype diversity with weight in Etawah Grade goats at Polewali Mandar Regency.

\section{METHODS}

The research was conducted in May-June 2014 at the Biotechnology, Integrated Laboratory, Faculty of Animal Science, University of Hasanuddin, Makassar. This research used 22 Etawah Grade 
female goats blood samples at Polewali Mandar Regency.

\subsection{Research Procedure}

The collected blood sample is then extracted with GeneJET Genomic DNA Extraction kit. Purified DNA using the spin column method and the DNA results were collected and stored at temperature of $20^{\circ} \mathrm{C}$. Furthermore, PCR-RFLP amplification using IGF-1 exon 4 primers with DNA sequences (forward5'-CACAGCGTATTATCCCAC-3' and reverse 5'-GACACTATGAGCCAGAAG-3'), annealing temperature of $60^{\circ} \mathrm{C}$, and the restriction enzyme used was HaeIII. The PCR-RFLP product sample was then viewing and photographing the agarose gel with UV transilluminator (gel documentation system).

\subsection{Data Analysis}

\subsubsection{Allele Frequency and Genotype Frequency}

The allele frequency of the IGF-1 gene is the ratio of an allele in each individual in a population to the number of all individuals. The allele frequency is computed using the following formulas [11]:

$$
X_{1}=\frac{2 N_{11}+N_{12}}{2 N}
$$

Information:

$\mathrm{X}_{1}=$ Allele frequencies $\mathrm{A}_{1}$ or $\mathrm{A}_{2}$

$\mathrm{N}_{11}=$ The number of samples in the genotype $\mathrm{A}_{11}$ or $\mathrm{A}_{21}$

$\mathrm{N}_{12}=$ The number of samples in the genotype $\mathrm{A}_{11}$ or $\mathrm{A}_{21}$

$\mathrm{N}=$ Total sample from population

The genotype frequency, namely the ratio of certain genotypes in a population. The genotype frequency was calculated using the following formulas [11]:

$$
\mathrm{X}_{11}=\frac{\mathrm{N}_{11}}{\mathrm{~N}}
$$

Information:

$\mathrm{X}_{11}=$ Genotype frequency $\mathrm{A}_{11}$ or $\mathrm{A}_{21}$

$\mathrm{N}_{11}=$ The number of samples in the genotype $\mathrm{A}_{11}$ or $\mathrm{A}_{21}$

$\mathrm{N} \quad=$ Total sample from population

\subsubsection{The Simple Linear Regression Model}

When there is only one independent variable in the linear regression model, the model is generally termed as a simple linear regression model. A simple linear regression model can obtain using statictics according to Sugiyono [12]. A regression line has three possibilities which will describe a positive, negative linear relationship, and there is not a linear relationship.

Furthermore, a correlation coefficient analysis was carried out to measure a relation between $\mathrm{X}$ and $Y$. The mathematical formula for computing $r$ and magnitude value of correlation coefficient can provide an interpretation using statictics according to Sugiyono [12].

Value of a correlation coefficient, which ranges from -1 to +1 . The + and - signs are used to positive and negative linear correlations based on criteria [12].

A coefficient of determination can be used to determine the ability a model explained variation in the dependent variable [13]. The coefficient of determination analysis using statictics according to Sugiyono [12].

\section{RESULT AND DISCUSSION}

\subsection{Allele Frequencies and Genotype Frequencies}

The allele and genotype frequencies differed in results. Frequency results were obtained based on the IGF-1 gene band pattern of exon 4 using the restriction enzyme HaeIII, as in Figure 1.

Figure 1 shows the results of the UV visualization of the transilluminator on PCR-RFLP for the IGF-1 exon 4 gene band pattern using the restriction enzyme HaeIII in the blood sample in Etawah Grade goats to produce genotypes AA (363 bp), AB (363, 264 and $99 \mathrm{bp}$ ), and BB (264 and $99 \mathrm{bp})$. The results of RFLP analysis are commonly used to detect the diversity in genes related to economic characteristics, such as milk production and quality [14]. Furthermore, stated that the PCR-RFLP method is one of the methods to continue the analysis of PCR products [15]. The PCR method uses nucleotide sequences which will later be recognized by restriction enzymes which are also known as restriction sites.

The IGF-1|HaeIII gene in Etawah Grade goats at Polewali Mandar Regency is polymorphic. This is in 
line with Tunnisa [16] research on Kacang goat and according to research that the IGF-1 gene in goats is polymorphic [17]. The same was true for Xinjiang goats

and Nanjiang goats where there were three genotypes [18].

The allele frequency and genotype frequency values in Etawah Grade goats at Polewali Mandar Regency as in Table 1.

The allele frequencies A (0.57) and B (0.43), as well as the genotypic frequencies of AA (0.32), AB (0.50), and BB (0.18) shown in Table 1, show the characteristics in Etawah Grade goats at Polewali Mandar Regency, where the allele $\mathrm{A}$ and $\mathrm{AB}$ genotype frequencies are the most frequent. The study by Arisuryanti [19] showed that the peculiarities of a population can be seen based on the frequency of genes and the frequency of their genotypes. Furthermore, the allele frequency and genotype frequency can change, this can be due to evolution, for example, mutations, migration, gene flow, genetic drift, and natural selection [20]

The results of the research on allele frequency and genotype frequency resulted in 2 (two) types of alleles and three (three) types of genotypes. The difference in allele frequency and genotype frequency values indicates a change in a population due to an indication of microevolution, namely the occurrence of small evolution at the gene level. Based on the results of the genotype frequency, it can describe simple functions of allele frequency. The frequencies of different genes influence by mutation, selection, sudden changes in genetic frequency, as well as factors in the occurrence of in-breeding and out-breeding [21].

\subsection{The Simple Linear Regression Model}

The simple linear regression model that shows the relationship of IGF-1|HaeIII locus in Etawah Grade goats, as in Figure 2.

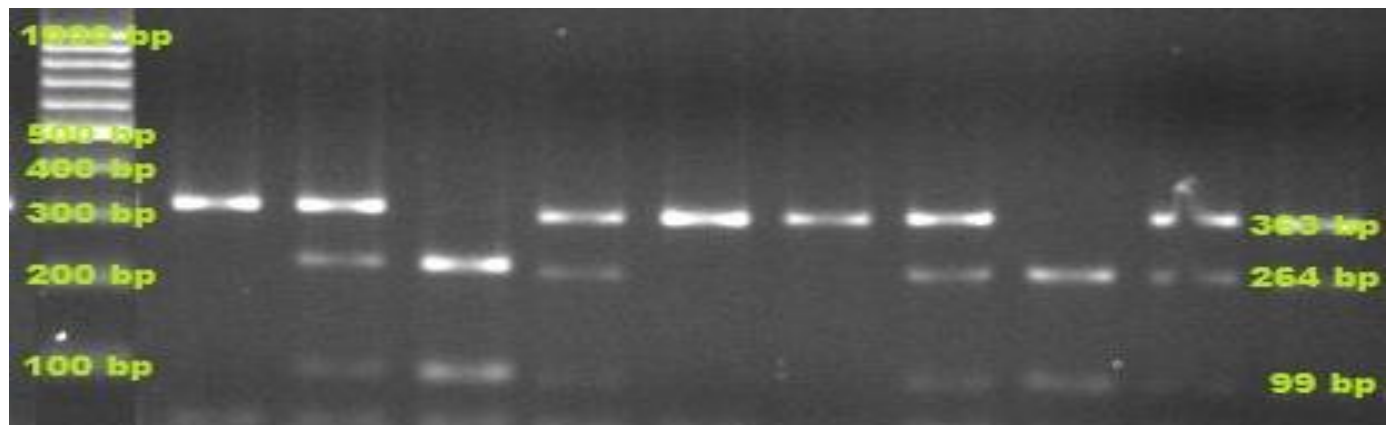

Figure 1. Ex-4 IGF-1 Gene Band Patterns on Agarose 2\% with the HaeIII Restriction Enzyme. AA genotype: 363 bp; AB genotype: 363, 264 and 99 bp; BB genotype: 264 and 99

Table 1. The Allele Frequency and Genotype Frequency Values at the IGF-1|HaeIII Locus in Etawah Grade goats at Polewali Mandar Regency

\begin{tabular}{cc}
\hline & Frequency \\
\hline Allele & Score \\
A & 0.57 \\
B & 0.43 \\
\hline Genotype & Score \\
\hline AA & $7(0,32)$ \\
AB & $11(0,50)$ \\
BB & $4(0,18)$ \\
\hline
\end{tabular}

Source: Processed data, 2020 


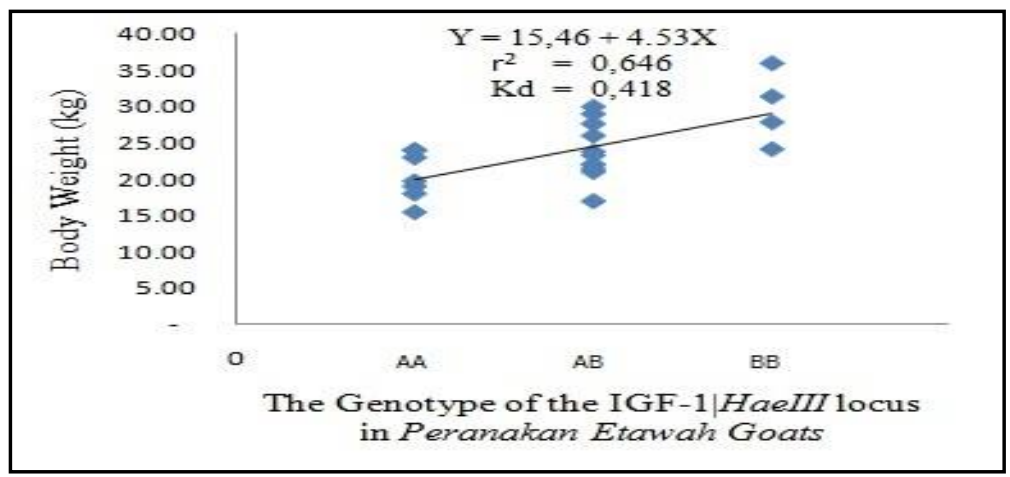

Figure 2. The Simple Linear Regression Analyis, the Correlation Coefficient, and the Coefficient of Determination of the relationship of IGF-1|HaeIII Locus with Weight in Etawah Grade goats at Polewali Mandar Regency.

Figure 2 shows results in simple linear regression following an equation $\mathrm{Y}=15,46+4,53 \mathrm{X}$, where the regression coefficient of the genotype variable for the IGF-1|HaeIII locus is 4,53 meaning that every addition to the genotype variable for the IGF1|HaeIII locus, there will be an increase in weight of body amounted to 4,53 . This shows that there is a positive (unidirectional) influence between the genotype of the IGF-1|HaeIII locus with weight in Etawah Grade goats at Polewali Mandar Regency. The genotype $\mathrm{BB}$ has a higher weight compared to the AA and AB genotypes. Thus, IGF is an important growth factor involved in a variety of physiological processes including cell differentiation, embryogenesis, lactation, metabolism, reproduction, and growth. The study by Misitahari [15] showed that growth hormone $(\mathrm{GH})$ gene through the IGF-1 induction plays an important role part of a wide network of growth factors and its derivatives [22].

The correlation is defined as the relationship between two variables. The results obtained show a correlation coefficient $r>0$ of 0,646 , it means that the data is a strong linear relationship of IGF1|HaeIII locus with weight in Etawah Grade goats at Polewali Mandar Regency. This strong relationship is seen based on the performance in Etawah Grade goats by measuring their weight. The study Curi [23] showed that the GH and IGF-I are important regulators of bone and muscle growth of livestock.

Furthermore, coefficient of determination should be used to determine the percentage the influence genotypes of IGF-1|HaeIII locus with weight in Etawah Grade goats at Polewali Mandar Regency. The coefficient of determination obtained was 0,418 , meaning that the genotype of the IGF-1|HaeIII locus affected weight in Etawah Grade goat by $41,8 \%$ and the rest was influenced by other variables. The study Nawawi [24] shows a proportion for diversity of a variable will be explained by the predictor variable or power from independent variables to explain dependent variables. Other studies related to growth hormone $(\mathrm{GH})$ coding genes regarding the diversity of the GH HaeIII gene haplotype in Boer goats [25], regulation of the IGF-1 to animal growth [26], the relationship the IGF-1 gene with growth in Nanjiang Huang goat [27]. The IGF-1 gene of local mediators of the GH action, is used of potential marker genes related to weight traits [28]. This is because the IGF1 gene is a growth factor that stimulates cell proliferation and differentiation [26].

\section{CONCLUSION}

The results obtained were that $\mathrm{AA}, \mathrm{AB}$, and $\mathrm{BB}$ genotypes of IGF-1 gene with the most allele frequency and genotype frequency is allele $\mathrm{A}$ and $\mathrm{AB}$ genotype, simple linear regression equation $\mathrm{Y}=$ $15,46+4,53 X$ with a correlation coefficient of 0,67 and a coefficient of determination is 0,42 . It was concluded that there was a strong the relationship of IGF-1 genotype diversity with weight in Etawah Grade goats.

\section{REFERENCES}

[1] J.W.H. Sirait, Strategi Pengembangan Usaha Peternakan Kambing Perah pada PT. Caprito A. P. Kecamatan Cariu Kabupaten Bogor, Skripsi, Fakultas Ekonomi dan Manajemen, Institut Pertanian Bogor, Bogor, 2009. [In Bahasa Indonesia]

[2] D.P.E. Putri, Studi Kasus Faciolosis yang Dipantau pada Pemeriksaan Daging Qurban Idul 
Adha 1427 H di Wilayah Jabodeta, Skripsi, Fakultas Kedokteran Hewan, Institut Pertanian Bogor, Bogor, 2008. [In Bahasa Indonesia]

[3] T.H. Sasongko, Analisis Strategi Pengembangan Usaha Peternakan Kambing dan Domba pada MT Farm Ciampea Bogor, Skripsi, Program Studi Manajemen Agribisnis, Fakultas Pertanian, Institut Pertanian Bogor, Bogor, 2006. [In Bahasa Indonesia]

[4] Prowel, Mudah dan Cepat Menghafal Biologi, Pustaka Book Publisher, Yogyakarta, 2010. [In Bahasa Indonesia]

[5] M.I. Misitahari, Pemberian Growth Hormone Menurunkan Kadar Tumot Necrosis Factor- $\alpha$ (TNF- $\alpha)$ ) pada Tikus Jantan yang Dislipidemia, Tesis, Program Magister, Universitas Udayana. Denpasar, 2011.

[6] P. Yuniarsih, Jakaria, Muladno, Eksplorasi Gen Growth Hormone Exon 3 pada Kambing Etawah Grade, Saanen dan Pesa Melalui Teknik PCRSSCP, Seminar Nasional Teknologi Peternakan dan Veteriner. Bogor, 2011. [In Bahasa Indonesia]

[7] E. Casas, S.N. White, T.L. Wheeler, S.D. Shackelford, M. Koohmaraie, D.G. Riley, C.C. Chase Jr, D.D. Johnson, T.P.L. Smith, Effect of Calpastatin and Micro-Calpain Markers in Beef Cattle on Tenderness Traits, Journal of Animal Science 84(3) (2006) 520-525. DOI: https://doi.org/ 10.2527/2006.843520x

[8] Maskur, C. Arman, C. Sumantri, E. Gurnadi, Muladno, A Novel Single Nucleotide Polymorphism in Exon 4 of Insulin-Like Growth Factor-1 Associated with Production Traits in Bali Cattle, Media Peternakan 35(2) (2012) 96101.

DOI:

https://doi.org/10.5398/medpet.2012.35.2.96

[9] F.S. Schenkel, S.P. Miller, X. Ye, S.S. Moore, J.D. Nkrumah, C. Li, J. Yu, I.B. Mandell, J.W. Wilton, J.L. Williams, Association of Single Nucleotide Polymorphisms in the Leptin Gene With Carcass and Meat Quality Traits of Beef Cattle, Jounal of Animal Science 83(9) (2005) 2009-2020.

DOI: https://doi.org/10.2527/2005.8392009x

[10] R. Misrianti, Identifikasi Keragaman Gen Pituitary-Specific Positive Transcription Factor1 (PIT-1) pada Kerbau Lokal (Bubalus bubalis) dan Sapi FH (Friesian-Holstein), Skripsi,
Fakultas Peternakan, Institut Pertanian Bogor, Bogor, 2009. [In Bahasa Indonesia]

[11] M. Nei, S. Kumar, Molecular Evolution and Phylogenetics, Oxford University Press, New York, 2000.

[12] Sugiyono, Metode Penelitian Kuantitatif, Kualitatif, dan R\&D, PT Alfabet, Bandung, 2016. [In Bahasa Indonesia]

[13] I. Ghozali, Aplikasi Analisis Multivariate dengan Program IBM SPSS, Universitas Diponegoro, Yogyakarta, 2012. [In Bahasa Indonesia]

[14] C. Sumantri, A. Anggraeni., A. Farajallah., D. Perwitasari, Keragaman Mikrosatelit DNA Sapi Perah Friesian-Holstein di Balai Pembibitan Ternak Unggul Baturaden, JITV 12(2) (2007) 124-133. [In Bahasa Indonesia]

[15] M.I. Misitahari, Pemberian Growth Hormone Menurunkan Kadar Tumot Necrosis Factor- $\alpha$ (TNF- $\alpha$ ) pada Tikus Jantan yang Dislipidemia, Tesis, Program Magister, Universitas Udayana, Denpasar, 2011.

[16] R. Tunnisa, Keragaman Gen IGF-1 pada Populasi Kambing Kacang di Kabupaten Jeneponto, Skripsi, Fakultas Peternakan Universitas Hasanuddin, Makassar, 2013. [In Bahasa Indonesia]

[17] X.Y. Lan, C.Y. Pan, H. Chen, C.Z. Lei, S.Q. Liu, Y.B. Zhang, L.J. Min, J. Yu, J.Y. Li, M. Zhao, S.R. Hu, The HaeIII and XspI PCRRFLPs Detecting Polymorphisms at The Goat IGFBP-3 Lokus, Small Ruminant Research 73 (2007) 283-286. DOI: https://doi.org/10.1016/j.smallrumres.2007.01.0 $\underline{01}$

[18] L. Wu-Jun, F. Guang-Xin, F. Yi, T. Ke-Chuan, H. Xi-Xia, Y. Xin-Kui, W. Mou, Y. Hui, H. Yong-Zhen, X. Jing-Jing, X. Ya-Ping, S. Yu, The Polymorphism of a Mutation of IGF-1 Gene on Two Goat Breeds in China, Jounal of Animalal Veterinary Advances 9(4) (2010) 790794.

DOI: http://doi.org/10.3923/javaa.2010.790.794

[19] T. Arisuryanti, H.S.N. Handayani, B.S. Daryono, Genetika Fakultas Biologi Universitas Gadjah Mada, Yogyakarta, 2007. [In Bahasa Indonesia] 
[20] T. Arisuryanti, B.S. Daryono, Genetika Populasi, Fakultas Biologi Universitas Gadjah Mada, Yogyakarta, 2007. [In Bahasa Indonesia]

[21] R.R. Noor, Genetika Ternak, Penebar Swadaya, Jakarta, 2000. [In Bahasa Indonesia]

[22] W. Qiong, F. Chao, L. Wu-Jun, F. Yi, Y. ShiGang, A Novel Mutation at Exon 4 of IGF-1 Gene in Three Indigenous Goat Breeds in China, Asian Journal of Animal Veterinary Advances 6(6) (2011) 627-635. DOI: http://doi.org/10.3923/ajava.2011.627.635

[23] R.A. Curi, H.N.D. Oliveira, A.C. Silveira, C.R. Lopes, Association Between IGF-1, IGF-IR and GHRH Gene Polymorphisms and Growth and Carcass Traits in Beef Cattle, Livestock Production Science 94(3) (2005) 159-167. DOI: http://doi.org/10.1016/j.livprodsci.2004.10.009

[24] Nawawi, Analisis Regresi dengan MS Excel 2007, PT Elex Medi Komputindo, Jakarta, 2010. [In Bahasa Indonesia]

[25] G.H. Hua, S.L. Chen, J.N. Yu, K.L. Cai, C.J. Wu, Q.L. Li, C.Y. Zhang, A.X. Liang, L. Han, L.Y. Geng, Z. Shen, D.Q. Xu, L.Q. Yang, Polymorphism of the Growth Hormone Gene and Its Association with Growth Traits in Boer Goat Bucks, Meat Science 81(2) (2009) 391395.

DOI:

https://doi.org/10.1016/j.meatsci.2008.08.015

[26] J.M. Pell, Regulation of Insulin-Like Growth Factor I Bioavailability in Growing Animals, Jounal of Animal Science 75(2) (1997) 20-31. DOI:

https://doi.org/10.2527/animalsci1997.75Supple ment 220x

[27] C. Zhang, W. Zhang, H. Luo, W. Yue, M. Gao, Z. Jia, A New Single Nucleotide Polymorphism in the IGF-1 Gene and Its Association with Growth Traits in the Nanjiang Huang Goat, Asian-Aust, Jounal of Animal Science 21(8) (2008) 1073-1079.

[28] P.C. Andrade, D.A. Grossi, C.C.P. Paz, M.M. Alencar, L.C.A. Regitano, D.P. Munari, Association of an Insulin-Like Growth Factor 1 Gene Microsatellite with Phenotypic Variation and Estimated Breeding Value of Growth Traits in Canchim Cattle, Anim Genet 39(5) (2008) 480-485. DOI: https://doi.org/10.1111/j.13652052.2008.01755.x 